\title{
Analisis Model Matematika Penyebaran Demam Berdarah Dengue dengan Fungsi Lyapunov
}

\author{
Syafruddin Side ${ }^{1}$, Ahmad Zaki ${ }^{1}$ dan Nurwahidah Sari ${ }^{1, \text { a) }}$ \\ ${ }^{1}$ Jurusan Matematika, Fakultas Matematika dan Ilmu Pengetahuan Alam, Universitas Negeri \\ Makassar, 90224 \\ a)nurwahidahsari@gmail.com
}

\begin{abstract}
Abstrak. Artike lini adalah penelitian teori dan terapan. Artikelini bertujuan untuk membahas mengenai model matematika SIRS untuk penyebaran Demam Berdarah Dengue. Data yang digunakanadalah data sekunder jumlah penderita penyakit Demam Berdarah Dengue dari Side pada tahun 2014. Pembahasan di mulai dari membangun model matematika SIRS penyakit Demam Berdarah Dengue, menentukan eksistensi model SIRS menggunakan fungsi Lyapunov, penentuan titik ekuilibrium, kemudian mencari analisis kestabilan titik ekuilibrium menggunakan fungsi Lyapunov, menentukan nilai bilangan reproduksi dasar $\left(R_{0}\right)$, membuat simulasi model, dan menginterpretasikannya. Dalam artikel ini diperoleh model matematika SIRS untuk penyakit Demam Berdarah Dengue, eksistensi model SIRS, dua titik ekuilibrium bebas penyakit dan endemik dari model SIRS, kestabilan global keseimbangan bebas penyakit dan endemik dari model SIRS dengan nilai bilangan reproduksi dasar $R_{0}=26,4760953$, ini menunjukkan bahwa penyakit Demam Berdarah Dengue berstatus epidemik.
\end{abstract}

Kata Kunci: Model Matematika, Penyebaran Penyakit, Demam Berdarah Dengue, Model SIRS, Fungsi Lyapunov

\begin{abstract}
This paper is theorethical and applied research. This paper aims to discus about SIRS mathematical models for the spread of dengue fever. The data used is a secondary data about the number of people with dengue fever disease from Side (2014). The discussion start from constructing SIRS models of dengue fever disease, determining the existence of SIRS models using Lyapunov function, determining equilibrium point, then looking for stability analysis of equilibrium point using Lyapunov function, determining reproduction number $\left(R_{0}\right)$, making models simulation, and interpreting it. In this paper, we obtained mathemathical models of SIRS for dengue fever disease, existence of SIRS models, disease-free and endemic equilibrium points of SIRS models, global stability of disease-free and endemic equilibrium of SIRS models with basic reproduction number $R_{0}=26,4760953$, it shows that dengue fever disease is epidemic status. $R_{0}=26,4760953$, This shows that Dengue Hemorrhagic Fever is an epidemic.
\end{abstract}

Keyword: Mathematical Model, Spread of Disease, Dengue Fever, SIRS Model, Lyapunov Function

\section{PENDAHULUAN}

Model matematika merupakan sekumpulan persamaan atau pertidaksamaan yang mengungkapkan perilaku suatu permasalahan yang nyata. Model matematika yang dibuat berdasarkan asumsi-asumsi (Maesaroh, 2013). Model matematika yang telah dibentuk akan dilakukan analisis, agar model yang dibuat representatif terhadap permasalahan yang dibahas. 
Banyak permasalahan yang timbul dari berbagai bidang ilmu, misalnya bidang kesehatan, kimia, biologi, dan lain-lain yang dapat dibuat model matematikanya (Maesaroh, 2013).

Model matematika untuk menganalisis penyebaran penyakit diantaranya ada model epidemi SIR (Susceptible-Infected-Recovered), SEIR (Susceptible-Exposed-Infected-Recovered), dan lainnya (Roni, 2011).

Model matematika penyebaran penyakit demam berdarah dengue yang dibahas dalam artikel ini adalah model epidemi SIRS. Model epidemi SIRS (Susceptible-Infective-RecoveredSusceptible) merupakan model penyebaran penyakit yang membagi populasi menjadi tiga subpopulasi, yaitu subpopulasi individu rentan (Susceptible), subpopulasi individu terinfeksi (Invective), dan subpopulasi individu sembuh (Recovered). Model epidemi SIRS merupakan suatu pengembangan dari model klasik SIR yang telah dikemukakan oleh Hethcote pada tahun 1976 dan 1989. Model epidemi SIR mengasumsikan bahwa individu yang sembuh dari penyakit tidak akan terjangkit penyakit lagi, sedangkan model SIRS mewakili suatu situasi ketika individu yang pernah terinfeksi dan sembuh tidak memperoleh kekebalan terhadap penyakit, sehingga kembali menjadi individu yang rentan untuk terjangkit kembali (Rohmah\& Kusumaniwahyu, 2014).

Kestabilan dari suatu system merupakan hal yang sangat penting untuk diketahui sehingga harus diperiksa secara teliti. Akan tetapi, menentukan kestabilan suatu system bukan hal yang mudah, terutama pada sistem nonlinear. Metode Lyapunov merupakan salah satu metode yang efektif dalam menentukan kestabilan sistem nonlinear (Ginting, 2014).

Virus demam berdarah dengue dibawa oleh dua jenis nyamuk yang disebut sebagai Aedes aegypti dan Aedes albopictus yang menyebarkan penyakit melalui gigitan mereka. Menurut WHO (2009), Aedes albopictus telah ditemukan di Asia dan kehadirannya telah terdeteksi dalam beberapa tahun terakhir. Namun, Aedes aegypti masih menjadi vector utama penularan virus dengue. Fakta lain yang menarik adalah pergeseran fenomena pasien dimana demam berdarah sebelumnya menyerang anak-anak usia dini, tetapi sekarang semua orang rentan terhadap demam berdarah dengue (WHO, 2009).Menurut Dr. Mozes demam berdarah disebabkan oleh empat jenis serotype virus yang terkait atau dapat dikatakan dalam satu keluarga virus dengue yaitu virus 1 (DEN1), virus 2 (DEN2), virus 3 (DEN3) dan virus 4 (DEN4). Tubuh mempunyai mekanisme membangun kekebalan pada virus dengue setelah pernah terinfeksi, kekebalan pada salah satu serotipe belum tentu pada serotipe lain. Kembali tertularnya seseorang yang sembuh dari demam berdarah dengue disebut secondary infection, maka mantan pasien demam berdarah dengue harus tetap waspada dan tak bisa hanya mengandalkan sistem kekebalan tubuh (Kompas, 2016).

Beberapa peneliti dan analisis model matematika untuk penyakit demam berdarah dengue telah banyak dilakukan diantaranyaAini dan Shodikin yang membahas tentang analisis kestabilan dan simulasi model penyakit DBD, dan Side \& Noorani yang membahas tentang Fungsi Lyapunov Model SIR dan SEIR untuk Penularan Penyakit Demam Berdarah.

Pada artikel ini dibahas mengenai analisis model matematika penyebaran demam berdarah dengue dengan fungsi lyapunov. Pengambilan data penelitian dalam artikel ini berasal dari penelitian sebelumnya (Side, 2014), membangun model SIRS, menganalisis kestabilan model SIRS dengan fungsi lyapunov, dan melakukan simulasi dari model SIRS pada penyebaran penyakit demam berdarah dengue.

Artikel ini bertujuan untuk mengetahui langkah-langkah membuat model dan mengetahui model matematika penyakit demam berdarah dengue, mengetahui analisis model dan analisis kestabilan model dengan menggunakan fungsi lyapunov, menginterpretasikan model dengan melakukan simulasi model. 


\section{Model SIRS}

Model epidemi SIRS (Susceptible-Infective-Recovered-Susceptible) merupakan model penyebaran penyakit yang membagi populasi menjadi tiga subpopulasi, yaitu subpopulasi individu rentan (Susceptible), subpopulasi individu terinfeksi (Invective), dan subpopulasi individu sembuh (Recovered). Model epidemi SIRS merupakan suatu pengembangan dari model klasik SIR. Model epidemi SIR mengasumsikan bahwa individu yang sembuh dari penyakit tidak akan terjangkit penyakit lagi, sedangkan model SIRS mewakili suatu situasi ketika individu yang pernah terinfeksi dan sembuh tidak memperoleh kekebalan terhadap penyakit, sehingga kembali menjadi individu yang rentan untuk terjangkit kembali (Rohmah \& Kusumani wahyu, 2014).

\section{Persamaan Diferensial Biasa Nonlinear}

Diberikan system persamaan diferensial nonlinear :

$$
\begin{gathered}
\dot{x}_{1}=f_{1}\left(x_{1}, x_{2}, \ldots, x_{n}\right), \\
\dot{x}_{2}=f_{2}\left(x_{1}, x_{2}, \ldots, x_{n}\right), \\
\vdots \\
\dot{x}_{n}=f_{n}\left(x_{1}, x_{2}, \ldots, x_{n}\right)
\end{gathered}
$$

dengan kondisi awal $x_{t}\left(t_{0}\right)=x_{0}, i=1,2, \ldots, n$

Sistem persamaan (1) dapat ditulis sebagai :

$$
\dot{x}=f(x)
$$

dengan $=\left(x_{1}, x_{2}, \ldots, x_{n}\right) \in R^{n}, f=\left(f_{1}, f_{2}, \ldots, f_{n}\right)^{T}, \quad$ dan $\quad$ kondisi $\quad$ awal $\quad x\left(t_{0}\right)=x_{0}=$ $\left(x_{10}, x_{20}, \ldots, x_{n 0}\right) \in R^{n}$. Selanjutnya notasi $x(t)=x\left(x_{0}, t\right)$ menyatakan solusi sistem (2) yang melalui $x_{0}($ Campbell \& Haberman, 2008).

\section{Titik Ekuilibrium}

Titik $\hat{x} \in R^{n}$ disebut titik ekuilibrium (titik keseimbangan) sistem (2) jika $f(\hat{x})=0$ (Perko, 2001).

\section{Kestabilan}

Diberikan $\hat{x} \in R^{n}$ titik ekuilibrium sistem (3)

1. Titikekuilibrium $\hat{x}$ dikatakan stabil lokal jika untuk setiap bilangan $\varepsilon>0$, terdapat bilangan $\delta=\delta(\varepsilon)>0$, sedemikian sehingga untuk setiap solusi $x(t)$ yang memenuhi $\left\|x\left(t_{0}\right)-\hat{x}\right\|<\delta$ berlaku $\|x(t)-\hat{x}\|<\varepsilon$, untuk setiap $t \geq t_{0}$.

2. Titikekuilibrium $\hat{x}$ dikatakan stabil asimtotik lokal, jika titik ekuilibrium $\hat{x}$ stabil dan jika terdapat $\delta_{0}>0$, sehingga untuk setiap solusi $x(t)$ yang memenuhi $\left\|x\left(t_{0}\right)-\hat{x}\right\|<\delta_{0}$ berlaku $\lim _{t \rightarrow \infty} x(t)=\hat{x}$.

3. Suatutitikekuilibrium $\hat{x}$ dikatakan tak stabil, jika tidak dipenuhi (i) (Perko, 2001).

\section{Linearisasi}

Diberikan $\hat{x}$ titik ekuilibrium sistem $\dot{x}=f(x)$ sistem $\hat{x}=J(f(\hat{x})) x$ disebut linearisasi dari system $\dot{x}=f(x)$ disekitar $\hat{x}$ (Olsder \& Woude, 2004). 


\section{Matriks Jacobian}

Diberikan $f=\left(f_{1}, f_{2}, \ldots, f_{n}\right)$ pada sistem (2) dengan $f_{1} \in C^{1}(E), i=1,2, \ldots, n$

$$
\text { Matriks } J(f(x))=\left[\begin{array}{cccc}
\frac{\partial f_{1}}{\partial x_{1}}(x) & \frac{\partial f_{1}}{\partial x_{2}}(x) & \cdots & \frac{\partial f_{1}}{\partial x_{n}}(x) \\
\frac{\partial f_{2}}{\partial x_{1}}(x) & \frac{\partial f_{2}}{\partial x_{2}}(x) & \cdots & \frac{\partial f_{2}}{\partial x_{n}}(x) \\
\vdots & \vdots & \ddots & \vdots \\
\frac{\partial f_{n}}{\partial x_{1}}(x) & \frac{\partial f_{n}}{\partial x_{2}}(x) & \cdots & \frac{\partial f_{n}}{\partial x_{n}}(x)
\end{array}\right]
$$

Dinamakan matriks Jacobian dari $f \operatorname{dititik} x[10]$.

\section{Nilai Eigen danVektor Eigen}

Diberikan matriks koefisien konstan A berukuran nxn dan sistem persamaan diferensial biasa homogen $\dot{x}=A x, x(0)=x_{0}, x \in R^{n}$. Suatu vektor tak nol $x$ di dalam $R^{n}$ disebut vektor eigen dari A jika untuk suatu skalar $\lambda$ berlaku:

$$
A x=\lambda x
$$

Nilai skalar $\lambda$ dinamakan nilai eigen dari $A$.Untuk mencari nilai $\lambda$ dari $A$, maka sistem persamaan (4) dapat ditulis:

$$
(A-\lambda I) x=0
$$

Dengan $I$ adalah matriks identitas. Sistem persamaan (4) mempunyai solusi tak nol jika dan hanya jika

$$
P(\lambda)=|A-\lambda I|=0
$$

Persamaan (5) merupakan persamaan karakteristik matriks A (Anton, 2000).

\section{Kriteria Routh-Hurtwitz}

Diberikan polynomial berderajat $n \cdot P(\lambda)=\lambda^{n}+a_{1} \lambda^{n-1}+\cdots+a_{n}$, dengan koefisien bilangan real $a_{1}>0, i=1,2, \ldots, n$ (Olsder \& Woude, 2004).

\section{Bilangan Reproduksi Dasar}

Bilangan reproduksi dasar merupakan bilangan yang menunjukkan jumlah individu rentan yang dapat menderita penyakit yang disebabkan oleh satu individu terinfeksi. Bilangan tersebut diperlukan sebagai parameter untuk mengetahui tingkat penyebaran suatu penyakit. Bilangan reproduksi dasar diperoleh dengan menentukan nilai eigen dari matriks Jacobian dari suatu sistem persamaan (model) yang dihitung pada titik equilibrium bebas penyakit. Bilangan reproduksi dasar dilambangkan dengan $R_{0}$. Beberapa kondisi yang akan timbul, yaitu :

1. Jika $R_{0}<1$, maka penyakit akan menghilang.

2. $\mathrm{Jika}_{0}=1$, maka penyakit akan menetap.

3. Jika $R_{0}>1$, maka penyakit akan meningkat menjadi wabah (Mulisi, 2011).

\section{Fungsi Lyapunov}

Kestabilan dari suatu sistem merupakan hal yang sangat penting untuk diketahui sehingga harus diperiksa secara teliti. Akan tetapi, menentukan kestabilan suatu sistem bukan hal yang mudah, terutama pada sistem nonlinear. Metode Lyapunov merupakan salah satu metode yang efektif dalam menentukan kestabilan sistem nonlinear (Ginting, 2014). 
Berikut diberikan beberapa fungsi Lyapunov:

1. Fungsi Lyapunov Logaritma diperkenalkan oleh Goh untuk Sistem Lokta Volterra

$$
L\left(x_{1}, x_{2}, \ldots, x_{n}\right)=\sum_{i=1}^{n} c_{i}\left(x_{i}-x_{i}^{*}-x_{i}^{*} \ln \frac{x_{i}}{x_{i}^{*}}\right)
$$

2. Fungsi Lyapunov kuadratik bersama (common quadratic Lyapunov functions)

$$
V\left(x_{1}, x_{2}, \ldots, x_{n}\right)=\sum_{i=1}^{n} \frac{c_{i}}{2}\left(x_{i}-x_{i}^{*}\right)^{2}
$$

3. Fungsi Lyapunov kuadratik kompositt (composite quadratic function)

$$
W\left(x_{1}, x_{2}, \ldots, x_{n}\right)=\frac{c}{2}\left[\sum_{i=1}^{n}\left(x_{i}-x_{i}^{*}\right)\right]^{2} \text { (Luenberger, 1979). }
$$

\section{METODE PENELITIAN}

Penelitian yang dilakukan merupakan jenis penelitian kajian teori dan terapan. Yaitu, dengan mengkaji literatur-literatur yang berhubungan dengan pemodelan matematika yang dapat digunakan untuk memecahkan masalah dengan terlebih dahulu menyuun konep-konsep sesuai kebutuhan mengenai persamaan diferensial yang bertujuan untuk membentuk, menganalisis, dan melakukan simulasi untuk model matematika penyebaran demam berdarah dengue dengan fungsi lyapunov. Data yang digunakan dalam penentian ini adalah data sekunder jumlah penderita penyakit demam berdarah dengue dari penelitian Side pada tahun 2014.

Adapun langkah-langkah yang dilakukan dalam penelitian ini adalah sebagai berikut:

1. Membangun model SIRSuntukpenyebarandemam berdarah dengue.

a. Mengasumsikanvariabeldan parameter model SIRS.

b. Membentuk model SIRS.

2. Menganalisis model SIRS untuk penyebaran demam berdarah dengue dengan menggunakan fungsi Lyapunov.

a. Menganalisiseksistensi model SIRS menggunakan fungsi Lyapunov.

b. Menganalisis kestabilan global model SIRS

1) Menentukan titik tetap model SIRS.

2) Menentukan matriks Jacobian dari model SIRS.

3) Menentukan bilangan reproduksi dasar $\left(R_{0}\right)$ dari model SIRS.

4) Menganalisiskestabilan global keseimbanganbebaspenyakit model SIRS menggunakan fungsi Lyapunov.

5) Menganalisis kestabilan global keseimbangan epidemik model SIRS menggunakan fungsi Lyapunov.

3. Mengimplementasikan hasil simulasi model SIRS untuk penyebaran demam berdarah dengue menggunakan aplikasi Maple.

a. Mensubtitusikan data sekunder berupa nilai parameter yang diperoleh dari jurnal penelitian yang dilakukan oleh Side pada tahun 2014.

b. Mengolah data dengan menggunakan bantuan software Maple.

c. Menganalisis hasil simulasi.

d. Menarik kesimpulan yang diperoleh dari hasil pemecahan masalah sebagai jawaban atas permasalahan yang dirumuskan. 
Berdasarkan prosedur penelitian di atas maka dibentuk alur atau skema penelitian sebagai berikut:

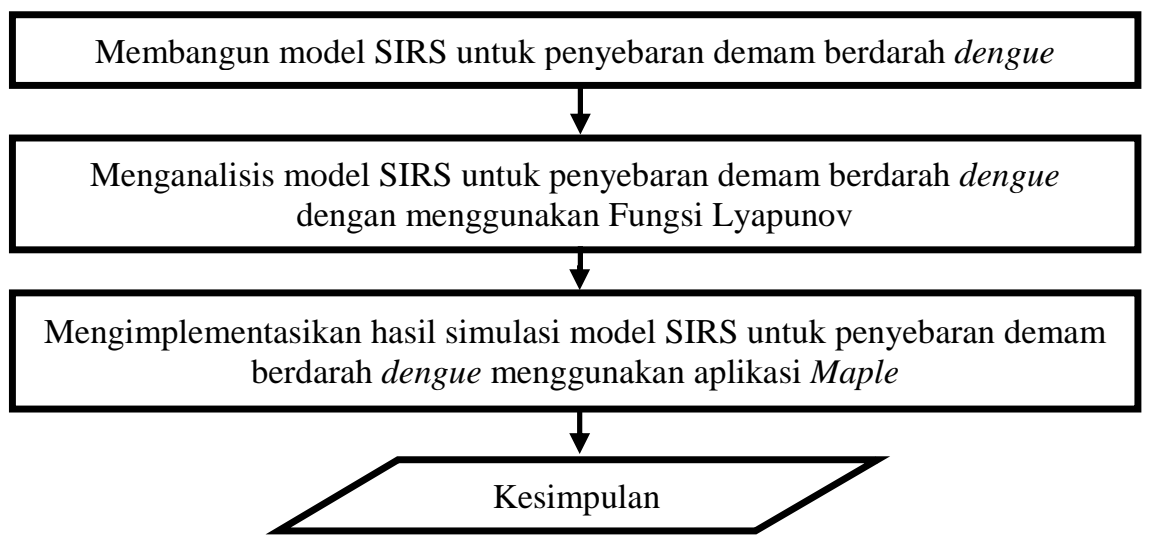

GAMBAR 1. Skema Penelitian

\section{HASIL DAN PEMBAHASAN}

\section{Model SIRS untuk Penyebaran Demam Berdarah Dengue}

Dalam model penyebaran demam berdarah dengue ini populasi manusia dibagi menjadi 3 kelas, yaitu kelas rentan/susceptible $\left(S_{h}\right)$ yang menyatakan kelas individu yang belum terjangkit penyakit demam berdarah dengue dan berpotensi terkena penyakit tersebut, kelas terinfeksi/infectious $\left(I_{h}\right)$ yang menyatakan kelas individu yang terinfeksi oleh virus demam berdarah dengue dan memiliki kemampuan menularkan virus dengue tersebut kepada vektor penular (nyamuk), kelas sembuh/recovery $\left(R_{h}\right)$ yang menyatakan kelas individu yang telah sembuh dari infeksi virus. Populasi nyamuk dibagi menjadi dua kelas, yaitu kelas $\operatorname{rentan}\left(S_{v}\right)$ dan kelas terinfeksi $\left(I_{v}\right)$.

Ada beberapa asumsi yang digunakan dalam pembentukan model, yaitu total populasi manusia dan nyamuk dianggap konstan, laju kelahiran dan laju kematian manusia dianggap sama, kelahiran pada populasi nyamuk dan manusia pada setiap kelas masuk ke dalam kelas rentan, setiap individu yang terdapat dalam populasi memiliki kemungkinan yang sama untuk tergigit nyamuk, tingkat gigitan nyamuk terinfeksi lebih tinggi daripada nyamuk rentan, setiap individu yang telah sembuh memiliki kemungkinan terinfeksi kembali sehingga masuk kembali ke dalam kelas rentan.

Perubahan yang terjadi pada setiap grup manusia dan nyamuk dapat ditafsirkan dalam bentuk Gambar 2.

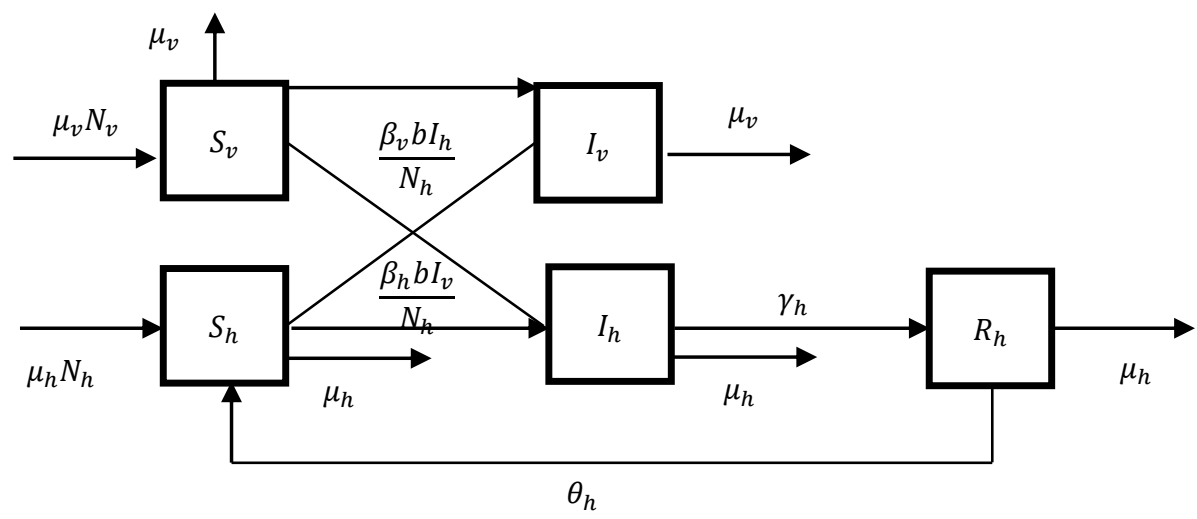

GAMBAR 2. Skema Populasi Manusia dan Vektor Model SIRS 
Gambar 2 dapat ditafsirkan dalam bentuk model matematika yaitu model interaksi Hos-Vektor yang merupakan persamaan differensial tidak linear sebagai berikut:

Populasi manusia

$$
\begin{gathered}
\frac{d S_{h}}{d t}=\mu_{h} N_{h}-\frac{\beta_{h} b}{N_{h}} I_{v} S_{h}-\mu_{h} S_{h}+\theta_{h} R_{h} \\
\frac{d I_{h}}{d t}=\frac{\beta_{h} b}{N_{h}} I_{v} S_{h}-\left(\mu_{h}+\gamma_{h}\right) I_{h} \\
\frac{d R_{h}}{d t}=\gamma_{h} I_{h}-\left(\mu_{h}+\theta_{h}\right) R_{h}
\end{gathered}
$$

Populasi vektor

$$
\begin{gathered}
\frac{d S_{v}}{d t}=\mu_{v} N_{v}-\frac{\beta_{v} b}{N_{h}} I_{h} S_{v}-\mu_{v} S_{v} \\
\frac{d I_{v}}{d t}=\frac{\beta_{v} b}{N_{h}} I_{v} S_{v}-\mu_{v} I_{v}
\end{gathered}
$$

\section{Analisis Model SIRS untuk Penyebaran Demam Berdarah Dengue}

Analisis kestabilan Model SIRS

\section{Eksistensi Model SIRS}

Perubahan yang terjadi dalam setiap populasi manusia dan nyamuk dapat ditafsirkan sebagai model matematika dari interaksi host-vector yang merupakan persamaan diferensial non-linear sebagai berikut:

$$
\begin{gathered}
\frac{d S_{h}}{d t}=\mu_{h} N_{h}-\frac{\beta_{h} b}{N_{h}} I_{v} S_{h}-\mu_{h} S_{h}+\theta_{h} R_{h} \\
\frac{d I_{h}}{d t}=\frac{\beta_{h} b}{N_{h}} I_{v} S_{h}-\left(\mu_{h}+\gamma_{h}\right) I_{h} \\
\frac{d R_{h}}{d t}=\gamma_{h} I_{h}-\left(\mu_{h}+\theta_{h}\right) R_{h} \\
\frac{d S_{v}}{d t}=\mu_{v} N_{v}-\frac{\beta_{v} b}{N_{h}} I_{h} S_{v}-\mu_{v} S_{v} \\
\frac{d I_{v}}{d t}=\frac{\beta_{v} b}{N_{h}} I_{v} S_{v}-\mu_{v} I_{v}
\end{gathered}
$$

Semua variabel dan parameter model adalah non-negatif dan dapat dilihat dengan mudah pada sistem persamaan (11), octant non-negatif $R_{+}^{5}$ adalah positif invarian. Berdasarkan sistem persamaan (11) diperoleh hasil seperti pada Teorema 1.

Teorema 1.

Misalkan $\left(S_{h}(t)>0, I_{h}(t)>0, R_{h}(t)>0, S_{v}(t)>0, I_{v}(t)>0\right)$ menjadi penyelesaian sistem persamaan (11) dengan keadaan awal $\left(S_{0 h}, I_{0 h} \cdot R_{0 h}, S_{0 v}, I_{0 v}\right)$ dan set padat

$$
D=\left\{\left(S_{h}(t), I_{h}(t), R_{h}(t), S_{v}(t), I_{h}(t)\right) \in R_{+}^{5}, L_{1} \leq N_{h}, L_{2} \leq \frac{A}{\mu_{v}}+\theta, \text { untuk } \theta>0\right\}
$$

Untuk model sistem persamaan (11), $D$ adalah satu set positif invarian yang mengkover semua penyelesaian dalam $R_{+}^{5}$.

Bukti:

Misalkan calon fungsi Lyapunov seperti persamaan berikut:

$$
L(t)=\left(L_{1}(t), L_{2}(t)\right)=\left(S_{h}+I_{h}+R_{h}, S_{v}+I_{v}\right)
$$

Derivatif waktu yang memenuhi persamaan (13)

$$
\frac{d L}{d t}=\left(\frac{d l_{1}}{d t}, \frac{d L_{2}}{d t}\right)=\left(S_{h}^{\prime}+I_{h}^{\prime}+R_{h}^{\prime}, S_{v}^{\prime}+I_{v}^{\prime}\right)
$$




$$
\begin{aligned}
& =\left(\mu_{h} N_{h}-\mu_{h} S_{h}-\mu_{h} I_{h}-\mu_{h} R_{h}, \mu_{v} N_{v}-\mu_{v} S_{v}-\mu_{v} I_{v}\right) \\
& =\left(\mu_{h} N_{h}-\mu_{h}\left(S_{h}+I_{h}+R_{h}\right), A-\mu_{v}\left(S_{v}+I_{v}\right)\right) \\
& =\left(\mu_{h} N_{h}-\mu_{h} L_{1}, A-\mu_{v} L_{2}\right)
\end{aligned}
$$

Dengan demikian, tidak sulit membuktikan bahwa:

$$
\left\{\begin{array}{c}
\frac{d L_{1}}{d t}=\mu_{h} N_{h}-\mu_{h} L_{1} \leq 0, \text { untuk } L_{1} \geq N_{h} \\
\frac{d L_{2}}{d t}=A-\mu_{v} L_{2} \leq 0, \text { untuk } L_{2} \geq \frac{A}{\mu_{v}}
\end{array}\right.
$$

Berdasarkan persamaan (14), diketahui bahwa $\frac{d L}{d t} \leq 0$ yang menerangkan bahwa D adalah suatu set invarian positif. Sebaliknya, dengan menyelesaikan sistem persamaan (14) diketahui bahwa:

$$
0 \leq\left(L_{1}(t), L_{2}(t)\right) \leq\left(N_{h}+L_{1}(0) e^{-\mu_{h} t}, \frac{A}{\mu_{v}}+L_{2}(0) e^{-\mu_{v} t}\right)
$$

dimana $L_{1}(0)$ dan $L_{2}(0)$ berturut-turut merupakan keadaan awal $L_{1}(t)$ dan $L_{2}(t)$. Oleh karena itu, jika $t \rightarrow \infty, 0 \leq\left(L_{1}(t), L_{2}(t)\right) \leq\left(N_{h}, \frac{A}{\mu_{h}}\right)$ dan dapat disimpulkan bahwa $\mathrm{D}$ adalah suatu set invarian positif yang mengkover semua penyelesaian dalam $R_{+}^{5}$. Ini membuktikan teorema.

Teorema ini menjamin eksistensi dari suatu kawasan yang awalnya tidak ditemukan nyamuk pembawa virus demam berdarah dengue kemudian berubah setelah ditemukannya nyamuk suspected tapi belum terinfeksi $\left(S_{v}(t)>0\right)$ dan terjangkiti virus demam berdarah dengue $\left(I_{v}(t)>0\right)$. Akibatnya, diperoleh populasi manusia yang positif suspected tetapi belum terinfeksi $\left(S_{h}(t)>0\right)$, terjangkiti $\left(I_{h}(t)>0\right)$, dan sehat kembali $\left(R_{h}(t)>0\right)$ terhadap penularan demam berdarah dengue. Teorema ini juga menghasilkan tahapan penyelidikan lebih lanjut tentang kasus demam berdarah dengue sehingga dapat mengidentifikasi secara detail tahap penyebaran dari wabah demam berdarah dengue hingga ketahap epidemik menggunakan model SIRS.

\section{Analisis Kestabilan Global}

System persamaan (11) untuk model SIRS mempunyai keseimbangan penyakit dengan titik keseimbangan $\left(N_{h}, 0,0, \frac{A}{\mu_{v}}, 0\right)$, untuk mencari nilai eigen $\lambda$, selesaikan persamaan $|A-\lambda I|=0$ yaitu

$$
\left.\| \begin{array}{ccccc}
-\mu_{h}-\lambda & 0 & \theta_{h} & 0 & -\beta_{h} b \\
0 & -\mu_{h}-\gamma_{h}-\lambda & 0 & 0 & \beta_{h} b \\
0 & \gamma_{h} & -\mu_{h}-\theta_{h}-\lambda & 0 & 0 \\
0 & -\beta_{v} b & 0 & -\mu_{v}-\lambda & 0 \\
0 & \beta_{v} b & 0 & 0 & -\mu_{v}-\lambda
\end{array}\right] \|=0
$$

Sehingga diperoleh persamaan nilai eigen sebagai berikut:

$$
\left(-\mu_{h}-\lambda\right)\left(-\mu_{v}-\lambda\right)\left(-\mu_{h}-\theta_{h}-\lambda\right)\left(\left(-\mu_{h}-\gamma_{h}-\lambda\right)\left(-\mu_{v}-\lambda\right)-\left(\beta_{h} b\right)\left(\beta_{v} b\right)\right)
$$

Dari persamaan nilai eigen diatas, laju pembiakan awal pada sistem persamaan (11) untuk model SIRS dapat ditentukan, yaitu seperti pada persamaan (15)

$$
R_{0}=\frac{\beta_{h} \beta_{v} b^{2}}{\mu_{v}\left(\mu_{h}+\gamma_{h}\right)}
$$

\section{Kestabilan Global Keseimbangan Bebas Penyakit Model SIRS}

Sistem persamaan (11) senantiasa mempunyai keseimbangan bebas penyakit (diseasefree $) \boldsymbol{x}_{d f e}=\left(S_{h}^{*}, I_{h}^{*}, R_{h}^{*}, S_{v}^{*}, I_{v}^{*}\right)=\left(N_{h}, 0,0, \frac{A}{\mu_{v}}, 0\right)$ yang setara dengan kehilangan penyakit. 
Bagian ini akan mengkaji tentang tingkah laku global keseimbangan bebas penyakit untuk persamaan (11).

Teorema 2.

Anggap bahwa $\left\{\begin{array}{l}\mu_{v}=\frac{\beta_{h} b S_{h}^{*}}{N_{h}} \\ \mu_{h}=\frac{\beta_{v} b S_{v}^{*}}{N_{h}}\end{array}\right.$

Dengan $\mu_{v}$ adalah laju untuk setiap populasi nyamuk yang berkurang disebabkan kematian secara alami dan $\mu_{h}$ adalah laju untuk setiap populasi manusia yang berkurang disebabkan kematian secara alami. Jika $R_{0} \leq 1$, maka keseimbangan bebas penyakit $\boldsymbol{x}_{d f e}$ ditahap global yang berasimptot stabil di $D$.

Bukti:

Misalkan calon fungsi Lyapunov sebagaimana persamaan (17)

$$
W(t)=\left(\left(S_{h}-S_{h}^{*} \ln S_{h}\right)+I_{h}+R_{h}+\left(S_{v}-S_{v}^{*} \ln S_{v}\right)+I_{v}\right.
$$

Dengan mendiferensialkan persamaan (4.15) terhadap waktu diperoleh persamaan (18).

$$
\begin{gathered}
\dot{W}(t)=\dot{S_{h}}\left(1-\frac{S_{h}^{*}}{S_{h}}\right)+\dot{I_{h}}+\dot{R_{h}}+\dot{S_{v}}\left(1-\frac{S_{v}^{*}}{S_{v}}\right)+\dot{I_{v}} \\
=\left(\mu_{h} N_{h}-\frac{\beta_{h} b I_{v}}{N_{h}} S_{h}-\mu_{h} S_{h}+\theta_{h} R_{h}\right)\left(1-\frac{S_{h}^{*}}{S_{h}}\right)+\frac{\beta_{h} b I_{v}}{N_{h}} S_{h}-\mu_{h} I_{h}-\gamma_{h} I_{h}+\gamma_{h} I_{h}-\mu_{h} R_{h}- \\
\quad \theta_{h} R_{h}+\left(A-\frac{\beta_{v} b I_{h}}{N_{h}} S_{v}-\mu_{v} S_{v}\right)\left(1-\frac{S_{v}^{*}}{S_{v}}\right)+\frac{\beta_{v} b I_{v}}{N_{h}} S_{v}-\mu_{v} I_{v} \\
=\mu_{h} N_{h}\left(1-\frac{S_{h}^{*}}{S_{h}}\right)+\mu_{h} S_{h}^{*}\left(1-\frac{S_{h}}{S_{h}^{*}}\right)-\theta_{h} R_{h}\left(\frac{S_{h}^{*}}{S_{h}}\right)+I_{h}\left(\frac{\beta_{v} b}{N_{h}} S_{v}^{*}-\mu_{h}\right)+I_{v}\left(\frac{\beta_{h} b}{N_{h}} S_{h}^{*}-\mu_{v}\right)+ \\
\quad A\left(1-\frac{S_{v}^{*}}{S_{v}}\right)+\mu_{v} S_{v}^{*}\left(1-\frac{S_{v}}{S_{v}^{*}}\right)-\mu_{h} R_{h}
\end{gathered}
$$

Menggunakan syarat-syarat (16), persamaan (18) dapat ditulis kembali sebagaimana persamaan (19)

$\dot{W}(t)=\mu_{h} N_{h}\left(1-\frac{S_{h}^{*}}{S_{h}}\right)+\mu_{h} S_{h}^{*}\left(1-\frac{S_{h}}{S_{h}^{*}}\right)-\theta_{h} R_{h}\left(\frac{S_{h}^{*}}{S_{h}}\right)+A\left(1-\frac{S_{v}^{*}}{S_{v}}\right)+\mu_{v} S_{v}^{*}\left(1-\frac{S_{v}}{S_{v}^{*}}\right)-\mu_{h} R_{h}(19)$

Perhatikan bahwa pada D, diketahui $S_{h}^{*}=N_{h}$ dan $S_{v}^{*}=\frac{A}{\mu_{v}}$. Dengan ini, persamaan (19) menjadi persamaan (20)

$$
\begin{gathered}
\dot{W}(t)=\mu_{h} N_{h}\left(2-\frac{S_{h}^{*}}{S_{h}}-\frac{S_{h}}{S_{h}^{*}}\right)-\theta_{h} R_{h}\left(\frac{S_{h}^{*}}{S_{h}}\right)+A\left(2-\frac{S_{v}^{*}}{S_{v}}-\frac{S_{v}}{S_{v}^{*}}\right)-\mu_{h} R_{h} \\
=-\mu_{h} N_{h} \frac{\left(S_{h}-S_{h}^{*}\right)^{2}}{S_{h} S_{h}^{*}}-\theta_{h} R_{h}\left(\frac{S_{h}^{*}}{S_{h}}\right)-A \frac{\left(S_{v}-S_{v}^{*}\right)^{2}}{S_{v} S_{v}^{*}}-\mu_{h} R_{h}
\end{gathered}
$$

Oleh karena itu, $\dot{W}(t) \leq 0$ dan dengan menggunakan lanjutan LaSalle kaedah Lyapunov, set terbatas yang ditetapkan setiap penyelesaian adalah yang terkandung dalam set invarian terbesar dengan $S_{h}=S_{h}^{*}, R_{h}=0$, dan $S_{v}=S_{v}^{*}$ adalah singleton $\left\{\boldsymbol{x}_{d f e}\right\}$. Ini berarti bahwa keseimbangan bebas penyakit $\boldsymbol{x}_{d f e}$ adalah ditahap global berasimptot stabil pada D. ini menyimpulkan bukti teorema.

Teorema kestabilan global model SIRS ini menjelaskan tentang suatu tahapan dari keberadaan kasus demam berdarah seperti dalam teorema 1. Tahapan ini menjelaskan bahwa jika seorang individu terinfeksi demam berdarah, $R_{0} \leq 1$ tidak akan menyebabkan individu yang lain terinfeksi. Ini berarti bahwa di kawasan ini penyakit demam berdarah masih dapat dikawal dan berada pada tahap yang tidak mengkhawatirkan. 


\section{Kestabilan Global KeseimbanganEpidemik Model SIRS}

Model untuk host-vector dalam sistem persamaan (11) dapat disederhanakan pada sistem persamaan (21)

$$
\begin{gathered}
\frac{d S_{h}}{d t}=\mu_{h} N_{h}-\frac{\beta_{h} b}{N_{h}} I_{v} S_{h}-\mu_{h} S_{h}+\theta_{h} R_{h} \\
\frac{d I_{h}}{d t}=\frac{\beta_{h} b}{N_{h}} I_{v} S_{h}-\left(\mu_{h}+\gamma_{h}\right) I_{h} \\
\frac{d S_{v}}{d t}=\mu_{v} N_{v}-\frac{\beta_{v} b}{N_{h}} I_{h} S_{v}-\mu_{v} S_{v} \\
\frac{d I_{v}}{d t}=\frac{\beta_{v} b}{N_{h}} I_{v} S_{v}-\mu_{v} I_{v}
\end{gathered}
$$

Sistem persamaan (21) mempunyai titik keseimbangan

$\boldsymbol{x}_{e e}=\left(S_{h}^{* *}, I_{h}^{* *}, S_{v}^{* *}, I_{v}^{* *}\right) \in D$ yang dikatakan keseimbangan endemik dan memenuhi $S_{h}^{* *}, I_{h}^{* *}, S_{v}^{* *}, I_{v}^{* *}>0$ dengan

$$
\begin{gathered}
I_{h}^{* *}=\frac{n_{h}\left(-\mu_{v} N_{h}\left(\mu_{h}+\gamma_{h}\right)+\beta_{h} \beta_{v} b^{2} N_{v}\right)\left(\mu_{h}+\theta_{h}\right)}{\left(\left(\mu_{h}+\theta_{h}\right)\left(\mu_{h}+\gamma_{h}\right) N_{h}+\beta_{h} b N_{v}\left(\mu_{h}+\gamma_{h}+\theta_{h}\right)\right) \beta_{v} b}, \\
I_{v}^{* *}=\frac{\beta_{h} \beta_{v} b^{2} N_{v} \theta_{h}+\beta_{h} \beta_{v} b^{2} \mu_{h} N_{v}-\gamma_{h} \theta_{h} \mu_{v} N_{h}-\gamma_{h} \mu_{h} \mu_{v} N_{h}-\theta_{h} \mu_{h} \mu_{v} N_{h}-\mu_{h}^{2} \mu_{v} N_{h}}{\beta_{h} b\left(\beta_{v} b \theta_{h}+\beta_{v} b \mu_{h}+\gamma_{h} \mu_{v}+\theta_{h} \mu_{v}+\mu_{h} \mu_{v}\right)} \text { dan } S_{v}=S_{v}^{* *} .
\end{gathered}
$$

Teorema berikut memberikan penjelasan tentang global keseimbangan endemik sistem persamaan (21).

Teorema 3.

Jika $R_{0}>1$, maka keadaan keseimbangan positif endemik persamaan (21) wujud dan ditahap global berasimptot stabil pada $\mathrm{D}$, dengan andaian bahwa

$$
\left\{\begin{array}{c}
\mu_{v}=\frac{A}{S_{v}^{* *}} \\
N_{h}=S_{h}^{* *} \\
b=\frac{A\left(\mu_{h}+\gamma_{h}\right)}{r \mu_{h} \beta_{v} S_{v}^{* * 2}}
\end{array}\right.
$$

Dengan $\mu_{v}$ adalah laju untuk setiap populasi nyamuk yang berkurang disebabkan kematian cecara alami, $N_{h}$ adalah jumlah populasi manusia yang sama dengan jumlah berpotensi untuk dijangkiti virus demam berdarah, $b$ adalah rata-rata gigitan nyamuk berpotensi dijangkiti dengan $r$ adalah laju hubungan yang mencukupi dari manusia kepada nyamuk sebagai vektor.

Bukti:

Misalkan calon fungsi Lyapunov sebagaimana persamaan (23)

$$
V(t)=\left(S_{h}-S_{h}^{* *} \ln S_{h}\right)+I_{h}+\frac{\left(\mu_{h}+\gamma_{h}\right)}{r S_{v}^{* *}}\left(S_{v}-S_{v}^{* *} \ln S_{v}\right)+\frac{\left(\mu_{h}+\gamma_{h}\right)}{r S_{v}^{* *}} I_{v}
$$

Dengan $r=\frac{\beta_{h} b}{N_{h}}$ dan $l=\frac{\beta_{v} b}{N_{h}}$ memenuhi persamaan (24)

$\dot{V}(t)=\dot{S_{h}}\left(1-\frac{S_{h}^{* *}}{S_{h}}\right)+\dot{I}_{h}+\frac{\left(\mu_{h}+\gamma_{h}\right)}{r S_{v}^{* *}} \dot{S_{v}}\left(1-\frac{S_{v}^{* *}}{S_{v}}\right)+\frac{\left(\mu_{h}+\gamma_{h}\right)}{r S_{v}^{* *}} \dot{I}_{v}$ 


$$
\begin{aligned}
& =\mu_{h} N_{h}-\frac{\beta_{h} b I_{v}}{N_{h}} S_{h}-\mu_{h} S_{h}+\theta_{h} R_{h}-\mu_{h} N_{h} \frac{S_{h}^{* *}}{S_{h}}+\frac{\beta_{h} b I_{v}}{N_{h}} S_{h}^{* *}+\mu_{h} S_{h}^{* *}-\theta_{h} R_{h} \frac{S_{h}^{* *}}{S_{h}}+\frac{\beta_{h} b I_{v}}{N_{h}} S_{h} \\
& -\left(\mu_{h}+\gamma_{h}\right) I_{h}+\frac{A\left(\mu_{h}+\gamma_{h}\right)}{l S_{v}^{* *}}-\frac{l\left(\mu_{h}+\gamma_{h}\right) I_{h}}{l} \frac{S_{v}}{S_{v}^{* *}}-\frac{\mu_{v}\left(\mu_{h}+\gamma_{h}\right)}{l} \frac{S_{v}}{S_{v}^{* *}} \\
& -\frac{A\left(\mu_{h}+\gamma_{h}\right)}{l S_{v}}+\frac{l\left(\mu_{h}+\gamma_{h}\right) I_{h}}{l}+\frac{\mu_{v}\left(\mu_{h}+\gamma_{h}\right)}{l}+\frac{l\left(\mu_{h}+\gamma_{h}\right) I_{h}}{l} \frac{S_{v}}{S_{v}^{* *}} \\
& -\frac{\mu_{v}\left(\mu_{h}+\gamma_{h}\right)}{l} \frac{I_{v}}{S_{v}^{* *}} \\
& =\mu_{h} N_{h}\left(1-\frac{S_{h}^{* *}}{S_{h}}\right)+\mu_{h} S_{h}^{* *}\left(1-\frac{S_{h}}{S_{h}^{* *}}\right)+\theta_{h} R_{h}\left(1-\frac{S_{h}^{* *}}{S_{h}}\right)+r I_{v} S_{h}^{* *}-\left(\mu_{h}+\gamma_{h}\right) I_{h} \\
& +\frac{A\left(\mu_{h}+\gamma_{h}\right)}{l S_{v}^{* *}}-\frac{\mu_{v}\left(\mu_{h}+\gamma_{h}\right)}{l} \frac{S_{v}}{S_{v}^{* *}}-\frac{A\left(\mu_{h}+\gamma_{h}\right)}{l S_{v}}+\left(\mu_{h}+\gamma_{h}\right) I_{h}+\frac{\mu_{v}\left(\mu_{h}+\gamma_{h}\right)}{l} \\
& -\frac{\mu_{v}\left(\mu_{h}+\gamma_{h}\right)}{l} \frac{I_{v}}{S_{v}^{* *}} \\
& =\mu_{h} N_{h}\left(2-\frac{S_{h}^{* *}}{S_{h}}-\frac{S_{h}}{S_{h}^{* *}}\right)+\theta_{h} R_{h}\left(1-\frac{S_{h}^{* *}}{S_{h}}\right)+\frac{\mu_{v}\left(\mu_{h}+\gamma_{h}\right)}{l}\left(1-\frac{S_{v}}{S_{v}^{* *}}\right)+\frac{\mu_{v}\left(\mu_{h}+\gamma_{h}\right)}{l}-\frac{A\left(\mu_{h}+\gamma_{h}\right)}{l S_{v}}- \\
& \frac{\mu_{v}\left(\mu_{h}+\gamma_{h}\right)}{l} \frac{I_{v}}{S_{v}^{* *}}+r I_{v} S_{h}^{* *} \\
& =\mu_{h} N_{h}\left(2-\frac{S_{h}^{* *}}{S_{h}}-\frac{S_{h}}{S_{h}^{* *}}\right)+\theta_{h} R_{h}\left(1-\frac{S_{h}^{* *}}{S_{h}}\right)+\frac{A\left(\mu_{h}+\gamma_{h}\right)}{l}\left(2-\frac{S_{v}}{S_{v}^{* *}}-\frac{S_{v}^{* *}}{S_{v}}\right) \\
& =-\mu_{h} N_{h} \frac{\left(S_{h}-S_{h}^{* *}\right)^{2}}{S_{h} S_{h}^{* *}}+\theta_{h} R_{h}\left(1-\frac{S_{h}^{* *}}{S_{h}}\right)+\frac{A\left(\mu_{h}+\gamma_{h}\right)}{l} \frac{\left(S_{v}-S_{v}^{* *}\right)^{2}}{S_{v} S_{v}^{* *}} \\
& \dot{V}(t)=-\mu_{h} N_{h} \frac{\left(S_{h}-S_{h}^{* *}\right)^{2}}{S_{h} S_{h}^{* *}}-\theta_{h} R_{h}\left(1-\frac{S_{h}^{* *}}{S_{h}}\right)-\frac{A\left(\mu_{h}+\gamma_{h}\right)}{l} \frac{\left(S_{v}-S_{v}^{* *}\right)^{2}}{S_{v} S_{v}^{* *}}
\end{aligned}
$$

Oleh karena itu, keadaan pada persamaan (24) memastikan bahwa $\dot{V}(t) \leq 0$ untuk semua $S_{h}(t), I_{h}(t), S_{v}(t), I_{v}(t) \in D$ dan $\dot{V}(t)=0$, kesamaan ketat $\dot{V}(t)=0$ hanya memenuhi untuk $S_{h}=S_{h}^{* *}, I_{h}=I_{h}^{* *}, S_{v}=S_{v}^{* *}$, dan $I_{v}=I_{v}^{* *}$. Kemudian keseimbangan $\boldsymbol{x}_{e e}$ hanya himpunan positif invarian dari sistem persamaan (21) yang terkandung sepenuhnya dalam titik-titik keseimbangan

$L=\left\{\left(S_{h}(t), I_{h}(t), S_{v}(t), I_{v}(t)\right), S_{h}=S_{h}^{* *}, I_{h}=I_{h}^{* *}, S_{v}=S_{v}^{* *}, I_{v}=I_{v}^{* *}\right\}$ dan seterusnya oleh teorema kestabilan asimptot (LaSalle, 1976 dalam Side, 2014), keseimbangan positif endemik $\boldsymbol{x}_{e e}$ ditahap global berasimptot stabil pada D. ini membuktikan teorema.

Teorema kestabilan global untuk model SIRS pada tahapan ini menjelaskan bahwa jika satu individu terinfeksi demam berdarah, $R_{0}>1$ maka mengakibatkan individu yang lain juga akan terinfeksi. Ini berarti bahwa penyakit demam berdarah pada tahapan ini adalah endemik sebab tidak lagi dapat dikontrol dan berada pada tahap yang mengkhawatirkan, sehingga menjadi ancaman untuk populasi manusia di kawasan ini.

\section{Simulasi Model SIRS untuk Penyebaran Demam Berdarah Dengue}

Simulasi dilakukan karena pengamatan terhadap sistem sulit dilakukan secara langsung, selain itu dengan simulasi dapat dipelajari hal-hal yang bisa terjadi dalam dinamika populasi.

Pemilihan parameter didasarkan pada studi yang dilakukan oleh berbagai sumber terpercaya. Beberapa nilai parameter seperti yang menyangkut populasi, didasarkan pada asumsi tentang situasi penyakit yang paling umum. Nilai-nilai parameter yang diambil sehingga diperoleh $R_{0}>$ 1 disajikan pada Tabel 1. 
TABEL 1. Nilai parameter pada model SIRS untuk penyakit demam berdarah dengue

\begin{tabular}{clcc}
\hline Simbol & \multicolumn{1}{c}{ Parameter } & $\begin{array}{c}\text { Nilai } \\
\text { Parameter }\end{array}$ & Sumber \\
\hline$N_{h}$ & Jumlah Populasi Manusia & 7675893 & (Ginting, 2014) \\
$N_{v}$ & Jumlah Populasi Nyamuk & 10000 & Asumsi \\
$\mu_{h}$ & Angka kelahiran/kematian manusia & 0,000046 & (Ginting, 2014) \\
$\mu_{v}$ & Angka kelahiran/kematian nyamuk & 0,0323 & (Ginting, 2014) \\
$\beta_{h} b$ & Kemampuan interaksi $I_{v}$ dengan $S_{h}$ & 0,75 & (Ginting, 2014) \\
$\beta_{v} b$ & Kemampuan interaksi $I_{h}$ dengan $S_{v}$ & 0,375 & (Ginting, 2014) \\
$\gamma_{h}$ & Laju kesembuhan terhadap penyakit & 0,328833 & (Ginting, 2014) \\
$\theta_{h}$ & Laju penurunan kekebalan manusia & $\frac{1}{730}$ & Asumsi \\
& terhadap penyakit & & \\
\hline
\end{tabular}

Diperoleh formulasi model epidemik SIRS untuk kasus penyakit demam berdarah dengue sebagai berikut:

$$
\begin{gathered}
\frac{d S_{h}}{d t}=0,00004599708130-\left(0,2925185603 I_{v}+0,000046\right) S_{h}+\frac{1}{730} R_{h} \\
\frac{d I_{h}}{d t}=0,2925185603 I_{v} S_{h}-0,328879 I_{h} \\
\frac{d R_{h}}{d t}=0,328833 I_{h}-0,001415863014 R_{h} \\
\frac{d S_{v}}{d t}=0,03089172-\left(0,3750237953 I_{h}+0,0323\right) S_{v} \\
\frac{d I_{v}}{d t}=0,3750237953 I_{h} S_{v}-0,0323 I_{h}
\end{gathered}
$$

Dengan syarat awal yang akan digunakan dalam simulasi model ini adalah; Nilai $S_{h}(0), I_{h}(0)$, $R_{h}(0), S_{v}(0)$, dan $I_{v}(0)$ untuk model SIRS ditentukan seperti pada Tabel 2.

TABEL 2. Syarat awal model SIRS

\begin{tabular}{ccc}
\hline Variabel & Nilai & Sumber \\
\hline$S_{h}(0)$ & $\frac{7675406}{7675893}$ & (Ginting, 2014) \\
$I_{h}(0)$ & $\frac{487}{7675893}$ & (Ginting, 2014) \\
$R_{h}(0)$ & $\frac{450}{7675893}$ & Asumsi \\
$S_{v}(0)$ & $\frac{9564}{10000}$ & Asumsi \\
$I_{v}(0)$ & $\frac{560}{10000}$ & (Ginting, 2014) \\
\hline
\end{tabular}


Simulasi Komputer Model SIRS

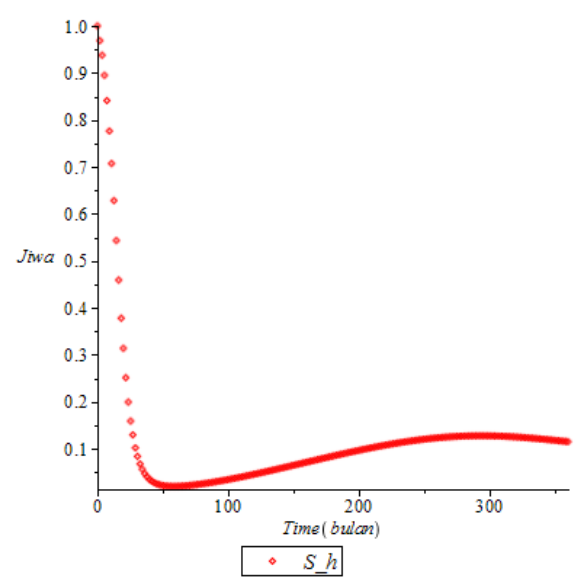

GAMBAR 3. Proporsi Individu Susceptible

Gambar 3 menunjukkan bahwa jumlah individu rentan mengalami penurunan secara drastis, namun memasuki bulan ke-60 jumlah individu rentan setiap bulannya semakin meningkat seiring berjalannya waktu. Setiap individu yang sehat namun rentan penyakit masuk ke dalam subpopulasi susceptible, individu pada subpopulasi ini akan rentan terhadap penyakit dan memiliki peluang yang sangat besar untuk terdeteksi penyakit.

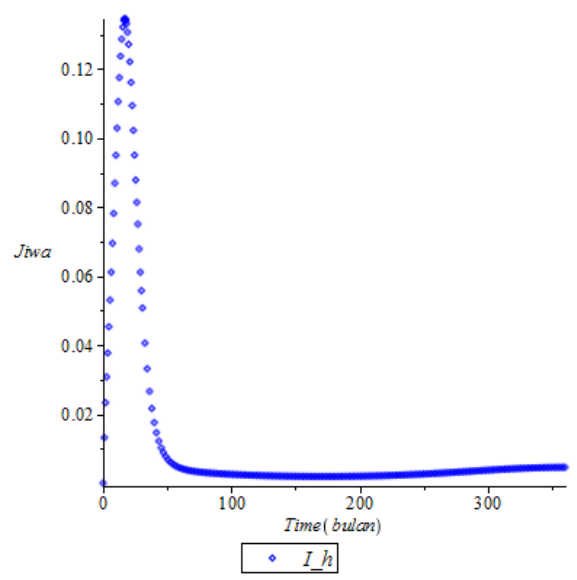

GAMBAR 4. Proporsi Individu Infected

Pada Gambar 4 menunjukkan bahwa jumlah individu yang terinfeksi pada bulan pertama naik secara drastis, namun pada bulan ke-20 jumlah individu yang terinfeksi menurun secara drastis, dikarenakan adanya jumlah pengurangan individu infected ke kelompok subpopulasi recovered, hal ini terjadi karena adanya individu yang sembuh dari penyakit. Maka setiap individu yang terinfeksi penyakit akan masuk ke dalam subpopulasi infected. 


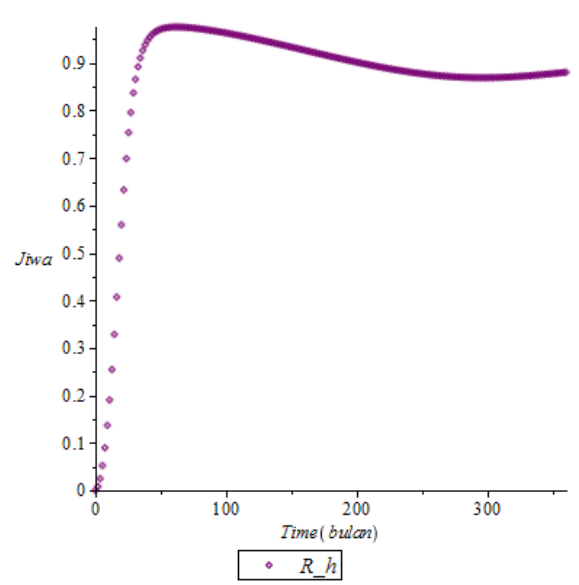

GAMBAR 5. Proporsi Individu Recovered

Gambar 5 menunjukkan bahwa jumlah individu recovered mengalami kenaikan seiring berjalannya waktu. Hal tersebut disebabkan karena adanya individu infected yang sembuh dari penyakit sehingga memasuki kelompok recovered. Namun, memasuki bulan ke-50 jumlah individu recovered mengalami penurunan, hal ini dikarenakan individu yang sembuh memiliki kemungkinan untuk terinfeksi kembali sehingga individu dapat menjadi rentan terkena penyakit dan kembali menjadi individu susceptible.

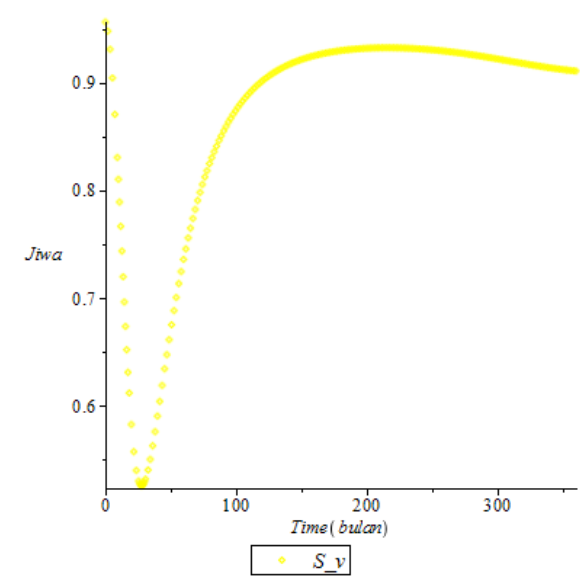

GAMBAR 6. Proporsi Vektor Susceptible

Gambar 6 menunjukkan bahwa jumlah vektor rentan pada bulan pertama menurun secara drastis, namun kemudian pada bulan ke-30 jumlah vektor rentan naik secara drastis. Setiap vektor yang sehat namun rentan penyakit masuk ke dalam subpopulasi susceptible, vektor pada subpopulasi ini akan rentan terhadap penyakit dan memiliki peluang yang sangat besar untuk terdeteksi penyakit. 


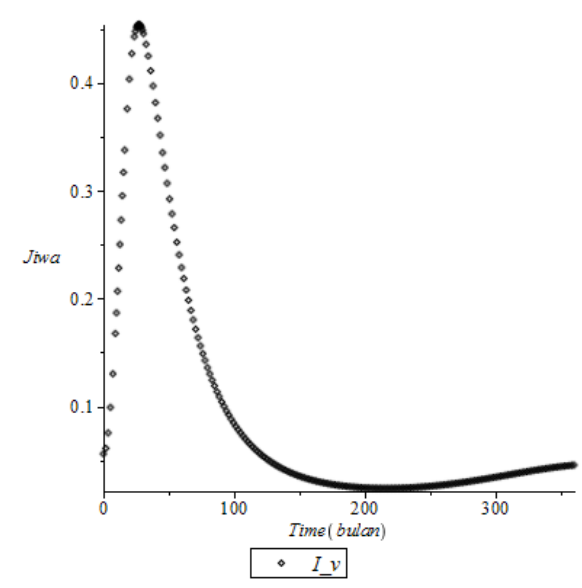

GAMBAR 7. Proporsi vektor Infected

Pada Gambar 7 menunjukkan bahwa jumlah vektor yang terinfeksi naik secara drastis, kemudian pada bulan ke-40 jumlah vektor yang terinfeksi menurun secara drastis, dikarenakan adanya jumlah pengurangan individu infected dikarenakan adanya vektor yang mati. Maka setiap vektor yang terinfeksi penyakit akan masuk ke dalam subpopulasi infected.

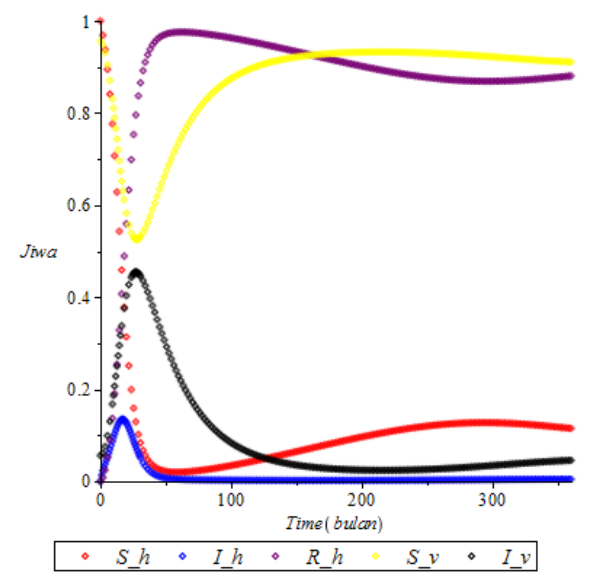

GAMBAR 8. Proporsi individu dan vektor model SIRS

Gambar 8 menunjukkan bahwa jumlah individu yang rentan mengalami penurunan secara drastis namun pada bulan ke-60 jumlah individu rentan setiap bulannya semakin meningkat seiring dengan berjalannya waktu. Jumlah individu yang terinfeksi pada bulan pertama naik secara drastis, namun pada bulan ke-20 jumlah individu yang terinfeksi menurun secara drastis. Jumlah individu recovered mengalami kenaikan seiring berjalannya waktu, namun memasuki bulan ke-50 jumlah individu recovered mengalami penurunan. Jumlah vektor rentan pada bulan pertama menurun secara drastis, namun kemudian pada bulan ke-30 jumlah vektor rentan naik secara drastis. Jumlah vektor yang terinfeksi naik secara drastis, kemudian pada bulan ke-40 jumlah vektor yang terinfeksi menurun secara drastis.

\section{Kadar Reproduksi Awal}

Nilai kadar reproduksi awal $R_{0}$ diperoleh dengan menggunakan nilai awal dan nilai parameter yang telah ditentukan dan diperoleh hasil sebagai berikut:

$$
R_{0}=\frac{\beta_{h} \beta_{v} b^{2}}{\mu_{v}\left(\mu_{h}+\gamma_{h}\right)}=\frac{(0,75)(0,375)}{0,0323(0,000046+0,328833)}=26,4760953 .
$$

Karena nilai $R_{0}>1$ maka hal ini menjadi status epidemik (KLB). 


\section{KESIMPULAN}

Berdasarkan hasil penelitian yang telah dipaparkan sebelumnya, dapat disimpulkan bahwa:

1. Model matematika SIRS penyebaran demam berdarah dengue dapat diekspresikan sebagai berikut:

Populasi manusia

$$
\begin{gathered}
\frac{d S_{h}}{d t}=\mu_{h} N_{h}-\frac{\beta_{h} b}{N_{h}} I_{v} S_{h}-\mu_{h} S_{h}+\theta_{h} R_{h} \\
\frac{d I_{h}}{d t}=\frac{\beta_{h} b}{N_{h}} I_{v} S_{h}-\left(\mu_{h}+\gamma_{h}\right) I_{h} \\
\frac{d R_{h}}{d t}=\gamma_{h} I_{h}-\left(\mu_{h}+\theta_{h}\right) R_{h}
\end{gathered}
$$

Populasi vektor

$$
\begin{gathered}
\frac{d S_{v}}{d t}=\mu_{v} N_{v}-\frac{\beta_{v} b}{N_{h}} I_{h} S_{v}-\mu_{v} S_{v} \\
\frac{d I_{v}}{d t}=\frac{\beta_{v} b}{N_{h}} I_{v} S_{v}-\mu_{v} I_{v}
\end{gathered}
$$

2. Analisis model SIRS untuk penyebaran demam berdarah dengue:

a. (Teorema 1) menghasilkan teorema mengenai jaminan eksistensi populasi manusia yang Suspected, Infected, dan Recovered dari demam berdarah dengue untuk model SIRS.

b. (Teorema 2)menghasilkan teorema mengenai tahapan status yaitu tahapan yang menjelaskan bahwa jika seorang individu terinfeksi demam berdarah dengue, $R_{0} \leq 1$ tidak akan menyebabkan individu yang lain terinfeksi untuk model SIRS. Ini berarti bahwa di kawasan ini penyakit demam berdarah masih dapat dikawal dan berada pada tahap yang tidak mengkhawatirkan.

c. (Teorema 3) menghasilkan teorema mengenai status epidemik yaitu tahapan yang menjelaskan bahwa jika satu individu terinfeksi demam berdarah dengue, $R_{0}>1$ maka mengakibatkan individu yang lain juga akan terinfeksi untuk model SIRS. Ini berarti bahwa satu individu yang terinfeksidemam berdarah dengue mengakibatkan infeksi bagiindividu lain atau penyakit demam berdarah dengue pada tahapan ini tidaklagi dapat dikontrol dan berada pada tahap yang mengkhawatirkan, sehingga menjadi ancaman untuk populasi manusia di kawasan ini.

3. Hasil simulasi diperoleh plot grafik yang menunjukkan bahwa jumlah individu Susceptible setiap bulannya selalu meningkat, jumlah individu Infected mengalami penurunan, dan jumlah individu Recovered semakin meningkat, namun setelah beberapa lama jumlah individu Recovered mengalami penurunan yang dapat disebabkan oleh berkurangnya kekebalan tubuh sehingga bisa menjadi individu Susceptible kembali. Untuk vektor Susceptible juga mengalami peningkatan, dan vektor Infected mengalami penurunan. Diperoleh bilangan reproduksi dasar $R_{0}=$ $\frac{\beta_{h} \beta_{v} b^{2}}{\mu_{v}\left(\mu_{h}+\gamma_{h}\right)}=\frac{(0,75)(0,375)}{0,0323(0,000046+0,328833)}=26,4760953$, ini berarti seseorang yang terinfeksi menyebabkan orang lain terkena penyakit yang sama, dengan kata lain terjadi wabah pada populasi tersebut.

\section{DAFTAR PUSTAKA}

Maesaroh, U. (2013). Model Matematika Untuk Kontrol Campak Menggunakan Vaksinasi.Universitas Islam Negeri Sunan Kalijaga, Yogyakarta.

Roni, T.P. (2011). Kestabilan Lokal Bebas Penyakit Model Epidemi SEIR dengan kumpulan Infeksi pada Periode Laten. Politeknik Negeri Padang, Padang. 
Rohmah, N. \& Kusumaniwahyu, W. M. (2014). Dinamik Model Epidemi SIRS dengan Laju Kematian Beragam.Jurnal Matematika Integratif, 10(1). 1-7.

Ginting, I. (2014). Teori Kestabilan Lyapunov. http://digilib.itb.ac.id/gld.php?mod=browse\&op=read\&id=jbptitbpp-gld-iwangintin19415 diakses pada tanggal 9 Oktober 2016.

WHO. (2009). Fact sheets: dengue and dengue haemorrhagic fever' [online] http://www.who.int/mediacentre/factsheets/fs117/en/

Kompas. (2016). Benarkah Kebal Virus DBD Jika Sudah Pernah Kena?. http://health.kompas.com/read/2016/05/03/120000823/Benarkah.Kebal.Virus.DBD.jika. Sudah.Pernah.Kena .diakses pada tanggal 9 Oktober 2016.

Side, S. (2014). Pemodelan Matematika SIR dan SEIR.Makassar: Badan Penerbit Universitas Negeri Makassar.

Campbell, S. L., \& Haberman, R. (2008). Introduction to Differential Equations with Dynamical System. New Jersey: Princeton University Press.

Perko, L. (2001). Diffrential Equations and Dynamical System $3^{\text {rd }}$. New York: Springer.

Olsder\& Woude, V. D. (2004). Mathematical System Theory. Belanda: Deflt Univercity of Technology.

Anton, H.(2000). Dasar-dasar Aljabar Linear. Batam: Interaksara.

Mulisi, S.(2011). Pengaruh Vaksinasi Terhadap Dinamika Populasi pada Model SIR (Suspected-Infected-Recovered). Institut Pertanian Bogor, Bogor.

Luenberger, D.(1979).Introduction to dynamical system theory, models, and applications.Canada: John Wiley \& Sons, Inc. 